\title{
Freedom of Expression from the Islamic Perspective
}

\section{Jallow AY*}

Martin de Tours School of Management and Economics, Assumption University, Bangkok, Thailand

\begin{abstract}
This paper examines the concept of the Islamic Perspective of Human Rights and Freedom of Expression as mentioned in the verses of the Quran. Freedom of expression today is almost exclusively a global phenomenon. Freedom exists in the sense that everyone can freely express his or her opinion as a prerequisite of fundamental human rights. Methodologically, the core differences between the Universal and Islamic understanding of freedom of expression are explained. This paper adopts a content analysis approach and argues that freedom in the Quran is natural, and it supersedes any earthly laws and instructions. Yet what is a human right for the Western world and constitutes a state law can be a crime for others. In Islam, nothing that questions its claims to truth may be publicly expressed. This paper will attempt to offer an analytical approach to confirm Islamic perspective and the innate phenomenon of freedom of expression and human rights.
\end{abstract}

Keywords: Freedom of expression; Human rights; Islam; Democracy; Religion

\section{Introduction}

\section{Freedom of Expression from the Islamic Perspective}

Suppression and repression are not acceptable according to the teachings of Islam and Islamic law based on the Holy Quran, and Sunnah maintains and upholds the right to freedom of expression but restricts it when it results in hampering the cause of unearthing truth, even where speech is offensive and hurtful. The Holy Quran teaches that one should express oneself through gentleness, courtesy, calmness, and discreetly through the concepts of hisbah and naseehah. The Quran maintains and upholds the right to freedom of religion, speech, and expression when done in a decent way.

Freedom of speech and expression is acknowledged in Islamic legal theory and is a component of its incredibly high ethical base. The objective of speech according to Islamic philosophy is to build up love, tolerance, social harmony, and understanding among members in order to ensure a peaceful coexistence. Islam limits freedom of expression where it is blasphemous or creates social disorder [1].

Within the Quran, there is no text that forbids the freedom of expression, limits it to certain extents, or suppresses it by any means. On the contrary, the Quran encourages people to discuss matters openly, protest, accept ideas or reject them, and bring about all pretexts and evidences that might be available to contest Islamic teachings. The Quran puts no restrictions on the freedom of expression whatsoever, to the extent that even the devil is allowed to speak openly. The Quran says:

[God] said: O Iblis [the devil], What prevents thee from prostrating thyself to one whom I have created with my hands? Art thou haughty? Or art thou one of the high [and mighty] ones? [Iblis] said: I am better than he: thou createdst me from fire, and him thou createdst from clay. [God] said: Then get thee out from here: For thou art rejected, accursed. And my curse shall be on thee till the Day of Judgment. [Iblis] said: O my Lord, give me then respite till the day the [dead] are raised. [God] said: Respite then is granted thee-till the Day of the Time Appointed. [Iblis] said: Then by Thy power, I will put them all in the wrong. Except Thy Servants amongst them, sincere and purified [by Thy Grace] [2].

The Quran adds:

[God] said: Get thee down from this: it is not for thee to be arrogant here: get out, for thou art of the meanest [of creatures]. He said: Give me respite till the day they are raised up. [God] said: Be thou among those who have respite. He said: Because thou hast thrown me out of the way, Lo, I will lie in wait for them on thy straight way: Then will I assault them from before and behind them, from their right and their left: Nor wilt thou find, in most of them, gratitude [for thy mercies].

If Iblis, or Satan, is given the freedom to speak up and try to convince people with his views, then one can easily conclude that ordinary people have the freedom to do so in Islamic teachings. Ordinary people supposedly are not as strong or mighty as Iblis, and they pose a modest danger to the system or the regime compared with the danger Iblis might pose.

The Quran does not ask Muslims to suppress nonbelievers and non-Muslims, but to bring them to open discussions and debate, and let everybody bring out his or her pretext and proofs. Everybody should have the chance to show the evidence he or she has without any kind of intimidation or fear. The Quran asserts this Al-Imran 2.

Islam gives everyone the right to exercise freedom of expression as long as they do not intrude upon the freedom and dignity of other people. There is no place for the propagation of evil and wickedness in Islam. It does not grant anybody the right to use abusive or offensive language in the name of criticism and freedom of speech.

The Quran does not force people to adopt Islam, oblige them to do so, or punish them if they do not. Islam does not force anyone: one has the freedom to believe or not, and faith remains one's choice. The freedom to form opinions is a unique opportunity in terms of freedom. The Quran brings it out because those who do not have enough information or data about a particular issue cannot form an educated opinion. One might make an opinion even with a shortage

*Corresponding author: Jallow AY, Martin de Tours School of Management and Economics, Assumption University, Bangkok, Thailand, Tel: 662675576970; E-mail: Alagiyorro@yahoo.com

Received August 15, 2015; Accepted October 19, 2015; Published October 29 2015

Citation: Jallow AY (2015) Freedom of Expression from the Islamic Perspective. J Mass Communicat Journalism 5: 278. doi:10.4172/2165-7912.1000278

Copyright: ( 2015 Jallow AY. This is an open-access article distributed under the terms of the Creative Commons Attribution License, which permits unrestricted use, distribution, and reproduction in any medium, provided the original author and source are credited. 
of information, but that would not be helpful in reaching the right decision about a certain matter. Islam is assertive in its teachings on decision-making because faults and mistakes are very costly in the life of individuals and for the community. That is why research and precision are essential in providing the necessary data required by rational and intelligent decision makers [3].

\section{Democracy and Islam}

Whether Islam is compatible with democracy is a misleading question; Islam and democracy are two different entities, although the two things cannot be divorced when dealing with politics in the Muslim world. Though Islam does not teach either democracy or dictatorship clearly, it is ready to impose ideological tenets upon Muslims [4].

Evidence has shown that dictatorship is inherent in both Islamic history and text. Early Caliphs and later Caliphs in numerous Islamic dynasties ruled their people without democratic principles. They simply justified their absolute political power with religious dogma, ignoring the voice of the people. It is true that the Muslim world has provided more dictators than any other modern society [4]. However, as illustrated above, Islam is compatible with human rights. Islam, like many other religions, is an old system of belief; democracy is a new advancement of the modern political system. But each can complement the other, as seen with the United Nation's Declaration of Human Rights and the similar document for Islam, the Cairo Declaration of Human Rights in Islam, created in 1990. The Cairo Declaration protects each individual from arbitrary arrest, torture, maltreatment, or indignity. It clearly does not condone abuse of power and authority. The Cairo Declaration was adopted by members of the Organization of the Islamic Conference (OIC), which is composed of eminent Islamic scholars. All of the countries that are part of the OIC officially adopted the Cairo Declaration in 2000.

And yet, though they both promote human rights, the spirit of the Cairo Declaration is fundamentally different from that of the Universal Declaration, since the former shares the Islamic understanding of human rights in terms of the Quran and of the Sharia. According to the Declaration, human rights derive from the dignity conferred to humanity by God's ascription of vice-regency to humanity, and Sharia is the fundamental basis for understanding and interpreting these rights [5].

Examined more closely, the Cairo Declaration is not an absolute statement of individual rights but is in some ways a list of conditions or obligations that individuals have to conform to under Sharia law. Freedom of expression in the Cairo Declaration, Article 22, stipulates that the right to express one's opinion freely is contingent on the statements being in conformity with Islam.

Everyone shall have the right to express his opinion freely in such manner as would not be contrary to the principles of the Sharia. Everyone shall have the right to advocate what is right, and propagate what is good, and warn against what is wrong and evil according to the norms of Islamic Sharia. Information is a vital necessity to society. It may not be exploited or misused in such a way as may violate sanctities and the dignity of prophets, [or] corrupt or harm society or weaken its faith [5].

According to these principles, one may only speak positively about Islam. This means that it is not only prohibited to criticize or blaspheme Islam or its prophet Muhammed (PBUH), but it is also prohibited to say anything that could undermine the confidence of Muslims in Islam, let alone publicly expressing statements of apostasy or missionizing for another religion.

Louis Brandeis, an American lawyer and later associate justice of the Supreme Court, said this about the need to be able to express oneself freely: "Public discussion is a political duty, and should be a fundamental principle. . . . Order cannot be secured merely through fear of punishment for its infraction, [and] it is hazardous to discourage thought, hope and imagination". He further noted that: fear breeds repression, that repression breeds hate, that hate menaces stable government, that the path of safety lies in the opportunity to discuss freely supposed grievances and proposed remedies, and that the fitting remedy for evil counsel is a good one. Believing in the power of reason as applied through public discussion, they eschewed silence coerced by law-argument of force in its worst form. Recognizing the occasional tyrannies of governing majorities, they amended the Constitution so that free speech and assembly should be guaranteed [6]

\section{Human rights and Islam}

Are true human rights an essentially Western construct? There is little doubt that the idea of human rights can be found in biblical sources. "The Bible talks about Man being created in the image of God, and St. Paul's letters emphasize the equality of mankind in Christ". But there is more to it than that. The natural law tradition goes back to the ancient Greeks, through the idea that human beings are endowed with inalienable rights which derive from an unwritten law or a higher principle. Then there is the Protestant Reformation, which asserted individual conscience as the foundation for an authentic faith [7]. English common law and its concern with inheritable rights is another noted source for the ideal of human rights. The privileging of the individual over the collective is a common theme in these traditions of human rights, and it underpins the Universal Declaration" [8]. Its preamble is replete with words such as "inalienable" and "inherent." The French Revolution's Declaration of the Rights of Man, the Magna Carta, writs of habeas corpus, Christian theology, and the U.S. Constitution and Bill of Rights have all been utilized as sources for modern human rights. So in a sense human rights are indeed a product of human decency and human tradition.

Human rights and their universal application are rightly seen as a defining challenge to the principles of Islamic life and civilization. The issue is now highly politicized, especially with the rise of Islam phobia all over the world with the imposition of Sharia and the war on terror, which wittingly or otherwise has conflated the notion of 'Islam with violence' in the minds of millions of people. Human rights have become an either/or issue: either Islam accepts the universality of the rights embodied in the UN Declaration and subordinates its own ethical foundations to it, or it opts out and charts its own way of formalizing human rights in Islam [8].

Although the authors of the Cairo Declaration may not have realized it at the time, the formulation used in the document was very much derived from modern preconceptions, garbed in the language of Sharia. Rights in Islam had previously been formulated in terms of duties and obligations of people to each other: to those in authority over them, to those subordinate to them, and, above all, to God.

As is indicated in the Cairo Declaration, whatever rights human beings have are the outcome of individuals and societies fulfilling their duties and responsibilities to each other. There are few rights which are explicitly recognized as such in the Quran-it establishes parental rights over children, for example, but most rights are in the nature of 
obligations. The rights of God over humanity are met through acts of worship and devotion [5]. The right to work exists because human beings have a duty to work and strive to improve their lot; the right to free expression exists because humanity has a duty to seek the truth and its fulfillment. Even in matters which are not on the surface contentious, such as the right to justice, the right arises in consequence of the fact that others-such as the state, the judiciary, or those in power-have not fulfilled their duty to provide or dispense justice.

What are the real challenges and significance of the Cairo Declaration? The declaration decries genocide, but several of the OIC member countries have massacred and terrorized their populations. Article 3 of the Cairo Declaration, which sets the principles of warfare, has been flagrantly ignored in most of the wars involving OIC member countries, for example in the Somali, Syrian, and Afghan civil wars and in the South of the Sudan. Articles dealing with torture and the inviolability of the individual are routinely ignored when Muslim states feel under threat. The indiscriminate slaughter of civilians by the state security apparatus in the Gambia in April 2000, resulting in the massacre of students, is another case in point, as are the measures deployed by the Egyptian government to combat militant Islamism. Article 20 bans torture and arrest without due cause and process, but torture and abuse of prisoners are common practice in the authoritarian states of the OIC, which includes nearly all the Arab countries and sub-Saharan Muslim countries. Article 6 guarantees the dignity of womankind, only to see its stipulations flouted by innumerable cases where women have been treated in a degrading and cruel manner on account of local tribal or social customs. Article 7 guarantees the rights of children, yet abused, abandoned, and mistreated children-let alone the widespread use of child labor-are a common feature of Muslim countries. Article 8 guarantees the right to justice. However, Muslim countries have probably some of the worst judicial systems, where corrupt judges, overloaded courts, and cumbersome and unfathomable legal systems conspire to undermine one of Islamic civilization's key props: the delivery of fair and speedy justice by incorruptible judges with real authority. The list goes on. Nearly every aspect of the Cairo Declaration is discounted in practice, and there is no effective mechanism, either governmental or one generated by civil society networks, to monitor and ensure compliance with its terms.

\section{Establishing True Freedom of Expression in Islamic Nations}

\section{Islam in and of itself not only respects but also demands freedom of expression}

The Quranic injunction to 'enjoin the good and shun the evil' is impossible to act upon if human beings are not allowed to speak and act freely. But the concept of hisbah, which embodies this injunction, has been perverted over time. In an erudite and comprehensive work, Freedom of Expression in Islam, the Afghan scholar Muhammad Hashim Kamali sets out specific principles from which an entire doctrine of free speech can be derived [9].

These principles are derived from the fact that many actions which are deemed praiseworthy in Islam can only be undertaken if one has the ability to express oneself freely. These include the proffering of sincere advice (Nasihah), the need to consult (shura), personal reasoning, the freedom to criticize, the freedom to express an opinion, the freedom of association, and the freedom of religion. These rights are not absolute. They are constrained both morally and legally. The moral constraints on freedom of expression are found in all the great religions. They are built-in safeguards that prevent injustice, abuse, and strife. And yet Islamic literature is full of irreverent and satirical poets, who caricatured rulers and the high and mighty [9].

Speech or action which encourages fitna (sedition and conspiracy) against legally constituted authority is a punishable offence. It would be no different from sanctioning those who conspire to overturn or undermine the legal order in any democratic state. And yet even where these are not the intent, the modern Muslim state has generally ignored the wide latitude given in Islam to exercise freedom of expression. But this has more to do with the structures of authoritarian states and governments than with Islam as such. Most Muslim governments attained power in a way that the Sharia would condemn: military coup d'état or assassinations and killings. Most of the world sees Muslims and Muslim rulers who flagrantly violate universal standards of human rights and freedoms, but does not pause to consider whether these violations are in any way allowed, tolerated, or condoned by Islam. It is automatically assumed that because they are perpetrated by Muslim dictators then they must have the sanction of the religion in whose name these violations are often committed or justified. But those who denigrate Islam's commitment to freedom of expression appear to have a strong case in the very special and limited issue of the Islamic position on apostasy and blasphemy. This is typical of the clash between the values of a secular modernity and a religiously inspired world, one which has been relegated to the past in most liberal democracies.

The defense of an Islamic norm for human rights is often hypocritical. The rhetoric of an Islamic basis for human rights frequently camouflages a cavalier disregard for every Islamic value that the countries in question purport to promote. Muslims' confidence in their own capacity to address the issue of human rights would be immeasurably boosted if the human rights record of the Islamic world were to live up to Islam's own codes of practice [8]. It is hopeless for Muslim countries to rail against a Western conspiracy to undermine Islam by imposing Western standards of human rights, if the human rights record in Muslim countries is dreadful. Muslims must denounce abuses, demand the abandonment of unacceptable conduct, and confront governments with their human rights record-framed, where possible, within the ethical norms of Islam. Islamic scholars will then find it more difficult to disguise their abusive behavior by using cultural norms or traditional customs as their justification; they will be unable to reject criticism with a blanket condemnation of human rights codes as Western invention.

A valid and effective Islamic version of human rights would not only serve the interest of Muslims, but might introduce a needed balance to the global human rights movement as well.

Islam came to free people, and there are strong evidences in the Quran that people are rational, responsible, and naturally capable of making choices. They are responsible to the extent that they are free, and they are creative to the extent that they are free and responsible. The advancement of humanity is tied with freedom, and the Quran assures that freedom provided the wheels of taking off [1].

Freedom of expression and speech in the holy Quran is natural, and it supersedes any earthly laws and instructions. Freedom in the Quran means the unity of the objective and the subjective, the social and the natural, and the individual and the plural. The teachings in the Quran are in harmony with natural innate powers, and lead finally to self-fulfillment both on the individual and social level. The freedom of expression is one of the most fundamental rights and functions as one of the most important benchmarks for any civilized society. Freedom 
Citation: Jallow AY (2015) Freedom of Expression from the Islamic Perspective. J Mass Communicat Journalism 5: 278. doi:10.4172/21657912.1000278

Page 4 of 4

of expression as human rights is considered one of the consequences for free democratic order.

\section{Conclusion}

The Quran is the uncontested basic and prime source of Islamic teaching without suppression or limits the fundamental rights of any Muslim. Thus, the Quran and Sunnah encourages Muslims to discuss matters openly, protest, accept ideas or reject them, and gives all pretexts and evidences that may be available to contest Islamic teachings. The privilege of free expression and the sharing of information is a basic human right, and it is one that has never been more vital than it is today. Our ability to express ourselves freely, within the confines of moral restraint, is an important aspect of our human identity. Throughout the world, citizens can and should promote freedom of expression as well as democracy, in order to help to guarantee these inalienable rights for people in every nation-both for now and into the future.

\section{References}

1. Bhat AM (2014) Freedom Of Expression From Islamic Perspective. Journal of Media and Communication Studies 6: 69-77.

2. The Holy Quran. Sura 3: Al-Imran: 79.

3. Kassem AS (2012) The Concept of Freedom in the Quran. American International Journal of Contemporary Research 2: 165-173.

4. Al-Makin (2011) Islam and Politics Yogyakarta, Jakarta.

5. (1990) Cairo Declaratio The Universal Islamic Declaration of Human Rights Islamic Council of Europe in 1981.

6. Jenkins H, Thorburn D (2003) Democracy and New Media. MIT Press, Cambridge.

7. Malik C (1972) God and Man in Contemporary Islamic Thoughts. American University of Beirut.

8. Allawi AA (2009) The Crisis of Islamic Civilization. Yale University Press, New Haven, CT.

9. Kamali MH (1988) Freedom of Expression in Islam. Ilmiah Publishers, Kuala Lumpur. 